\title{
Antigenic Comparison of Envelope Protein E between Japanese Encephalitis Virus and Some Other Flaviviruses Using Monoclonal Antibodies
}

\author{
By JUNKO KIMURA-KURODA* AND KOTARO YASUI \\ Department of Microbiology, Tokyo Metropolitan Institute for Neurosciences, 2-6, Musashidai, \\ Fuchu-shi, Tokyo I83, Japan
}

(Accepted 28 August 1986)

\section{SUMMARY}

The antigenic relationships between Japanese encephalitis (JE) virus and several other flaviviruses have been investigated using anti-JE virus monoclonal antibodies (MAbs). Seventeen MAbs directed against envelope protein $\mathrm{E}$ of $\mathrm{JE}$ virus were characterized and divided into eight MAb groups based on reactivity patterns in haemagglutination inhibition test, neutralization (N) test, ELISA and competitive binding assay with JE virus. The results suggest the existence of at least eight epitopes on the $\mathrm{E}$ protein of JE viruses. Analysis of cross-reactivity of the antibodies with several other flaviviruses indicated these findings. (i) JE virus, belonging to West Nile (WN) subgroup, is antigenically closely related to viruses in the same subgroup, i.e. Murray Valley encephalitis (MVE), WN and St. Louis encephalitis (SLE) viruses. Of these three viruses, JE virus has the closest relationship with MVE virus. (ii) WN virus is relatively close to JE virus, whereas SLE virus is the least closely related. (iii) Dengue viruses types 1 and 2, which belong to another subgroup of flaviviruses, show markedly less antigenic homology to JE virus. (iv) One of the critical $\mathrm{N}$ sites on the $\mathrm{E}$ protein showed JE virus specificity. (v) Some cross-reactive antibodies which did not neutralize JE virus showed low but significant $\mathrm{N}$ activity against several other flaviviruses. Mixtures of several MAbs, which showed different reactivity patterns, potentiated the $\mathrm{N}$ activity against not only JE virus but also other members of the WN subgroup of flaviviruses, namely MVE, WN and SLE viruses.

\section{INTRODUCTION}

Japanese encephalitis (JE) virus is one of about 60 distinct viruses in the newly established family Flaviviridae (Westaway et al., 1985) which are distributed broadly through the new and old world. Several flaviviruses, for example, JE, yellow fever (YF) and dengue (DEN) viruses, have high pathogenicity for humans, and two or more different types frequently overlap in certain areas. A particularly serious problem for public health has been caused by the overlap of $\mathrm{JE}$ and DEN viruses in Southeast Asia. This has complicated the problems of both vaccination and immunological response in the host. Flaviviruses show high cross-reactions in haemagglutination inhibition (HI) or complement fixation tests but low cross-reactions in the neutralization (N) test (Porterfield, 1980), and it is not yet known whether these cross-reactive antibodies play protective roles or not. On the basis of serological tests, especially $\mathrm{N}$ tests, flaviviruses are subdivided into subgroups or subcomplexes (Chamberlain, 1980; Porterfield, 1980), and JE virus belongs to the West Nile (WN) subgroup which includes WN, Murray Valley encephalitis (MVE), St. Louis encephalitis (SLE) and other viruses. This has been supported by evidence that cross-reactions in the $\mathrm{N}$ test are recognized within these WN subgroup viruses (Madrid \& Porterfield, 1974). The DEN viruses are in a separate subgroup, and $\mathrm{YF}$ virus is also separate.

These cross-reactions among flaviviruses reflect similarities between the major surface 
glycoprotein E (V3) of different viruses which express antigenic determinants correlated with biological properties, $\mathrm{N}$ and haemagglutination (HA) (Takegami et al., 1982a). Therefore, an understanding of the antigenic relationship of the $\mathrm{E}$ protein among flaviviruses in the same and in different subgroups is essential. Epitopes of the $E$ protein of several flaviviruses, $J E$ virus (Kimura-Kuroda \& Yasui, 1983), tick-borne encephalitis (TBE) virus (Heinz et al., 1983, $1984 b$ ), SLE virus (Mathews \& Roehrig, 1984; Roehrig et al., 1983), YF virus (Schlesinger \& Brandriss, 1983), WN virus (Peiris et al., 1982) and DEN virus (Gentry et al., 1982), have been analysed and divided into virus-specific, subgroup-reactive and flavivirus cross-reactive sites using monoclonal antibodies (MAbs). Recently, Buckley \& Gould (1985) and Gould et al. (1985) reported immunological relationships among flaviviruses by immunofluorescence and $\mathrm{N}$ tests using anti-YF MAbs. Bell et al. (1985) reported that the amino-terminal amino acid sequences of E proteins of three flaviviruses (YF, SLE and DEN-2) show significant homology. However, the antigenic relationship among WN subgroup viruses has not been studied in detail.

Here, we present the antigenic relationships of the $\mathrm{E}$ protein among several WN subgroup viruses (JE, MVE, WN and SLE) and other subgroup flaviviruses (DEN) using MAbs against the $\mathrm{E}$ protein of $\mathrm{JE}$ virus.

\section{METHODS}

Viruses. The viruses analysed in this study are listed in Table 1. Nakayama-Yoken (Nak) and Mie 44-1 (Mie) strains of JE virus were obtained through the courtesy of Dr H. Nakamura of the Nippon Institute for Biological Science. WN, MVE, SLE, DEN-1 and DEN-2 viruses were kindly provided by Dr A. Oya of the National Institute of Health of Japan. For immunization, JE viruses as immunogen were purified from the brain homogenates of infected suckling mice by sequential centrifugation in discontinuous and linear density gradients (Kimura-Kuroda \& Yasui, 1983). For ELISA, HI and $\mathrm{N}$ tests, all of the viruses were propagated in C6/36 cells cultivated in Eagle's MEM containing $10 \%$ heat-inactivated foetal bovine serum (FBS) and non-essential amino acids. The culture fluids of infected C6/36 cells were harvested after the appearance of c.p.e. The viruses in the culture fluids were purified by discontinuous density gradient centrifugation.

Preparation of MAbs. These were prepared against either JaGAr-01 (JaG) or Nak strain of JE virus as described previously (Kimura-Kuroda \& Yasui, 1983). The immunoglobulin class and subclass were determined by a modification of the ELISA technique or Ouchterlony gel diffusion test (Kimura-Kuroda \& Yasui, 1983).

Determination of specificity of MAbs. Specificity of MAbs was determined by radioimmunoprecipitation (RIP) of infected cell lysates using Staphylococcus aureus Cowan I strain (Laemmli, 1970; Takegami et al., 1983), except for IgG1 class which is known to bind weakly to staphylococcal Protein A. Infected C6/36 cells which were labelled with $15 \mu \mathrm{Ci} / \mathrm{ml} \mathrm{[35}$ Slmethionine were lysed with lysis buffer containing $0.5 \% \mathrm{NP} 40,50 \mathrm{mM}$-Tris $\mathrm{pH} 7.5$, $5 \mathrm{~mm}$-EDTA and $0.15 \mathrm{M}-\mathrm{NaCl}$ for $1 \mathrm{~h}$ at $0{ }^{\circ} \mathrm{C}$. The extract was centrifuged twice at 10000 r.p.m. for $10 \mathrm{~min}$ to remove nuclei. The supernatant was incubated with each sample of MAbs in the presence of $0.2 \% \mathrm{SDS}$ and incubated overnight at $4^{\circ} \mathrm{C}$. Immune complexes were precipitated by $S$. aureus Cowan I, washed, and boiled in Laemmli's electrophoresis loading buffer to elute immunoprecipitated antigens. The sample was subjected to SDS polyacrylamide slab gel electrophoresis (SDS-PAGE) and autoradiography.

The specificity of IgG1 class MAb was determined by Western blotting. Proteins included in JE virus-infected cell lysates were fractionated in $12.5 \%$ gels by SDS-PAGE and transferred to nitrocellulose membranes (Bio-Rad) (Towbin et al., 1979). The membrane was then incubated first with MAb specific for the antigen, washed, and incubated with goat peroxidase-labelled anti-mouse immunoglobulin serum (Cappel Laboratories). The antigen specific for each MAb was detected by incubation with peroxidase colour development reagent (Bio-Rad).

ELISA and competitive binding assay $(C B A)$. These were performed as previously described in detail (KimuraKuroda \& Yasui, 1983). Twenty to $40 \mathrm{HA}$ units of purified virus as antigen was dispensed into each well of a plastic Immulon U-microtitre plate (Dynatech). CBA was based upon competition between peroxidase-labelled and unlabelled MAbs for a previously determined limiting antigen in ELISA. Competitor antibodies were used at the limit concentration of $\log _{10} 4.0$ ELISA units, which showed maximum competition as described previously (Kimura-Kuroda \& Yasui, 1983). The percentage binding of peroxidase-labelled MAb was calculated by the absorbance in the presence of unlabelled competing MAbs. Horseradish peroxidase (HRPO)-labelled MAbs were prepared by the method of Nakane \& Kawaoi (1974).

Serological test. HI tests were performed by the method of Clarke \& Casals (1958), using 8 HA units of antigen and pigeon erythrocytes (Mori et al., 1965). Purified viruses from infected C6/36 cells were used as HA antigen.

The $\mathrm{N}$ tests for JE, MVE, WN and SLE viruses were done by a focus (plaque) assay method (Kimura-Kuroda \& Yasui, 1985). By this method, virus antigens on the infected cell surface were attacked by antiviral serum and complement, and foci (plaques) of cell c.p.e. were evident. The $\mathbf{N}$ tests for DEN-2 virus were performed by a modified focus assay of the PAP (peroxidase-anti-peroxidase) staining technique (Okuno et al., 1977). Briefly, the 
Table 1. Viruses analysed

\begin{tabular}{cllll}
$\begin{array}{c}\text { Genus } \\
\text { Flavivirus }\end{array}$ & \multicolumn{1}{c}{ Subgroup } & \multicolumn{1}{c}{ Species } & \multicolumn{1}{c}{ Strain } & \multicolumn{1}{c}{ Abbreviation } \\
& WN subgroup & Japanese encephalitis & JaGAr-01 & \multicolumn{1}{c}{ JaG } \\
& & (JE) & Mie 44-1 \\
& & Nakayama-Yoken & Nak \\
& & Murray Valley encephalitis & & MVE \\
& & West Nile & Egypt 101 & WN \\
& & St. Louis encephalitis & Parton & SLE \\
& Dengue subgroup & Dengue type 1 & Hawaii & DEN-1 \\
& & Dengue type 2 & Tr. 1751 & DEN-2 \\
Alphavirus & WEE subgroup & Sindbis & & SIN
\end{tabular}

infectivity of the mixtures of virus and each MAb was assayed on confluent Vero cell monolayers in four-chamber tissue culture slides (Lab-Tek). The infected cells at 3 days post-infection were fixed with cold acetone for $5 \mathrm{~min}$. They were then treated for $1 \mathrm{~h}$ at $37^{\circ} \mathrm{C}$ with HRPO-labelled MAb 23, which was flavivirus cross-reactive (Kimura-Kuroda \& Yasui, 1983). After washing with phosphate-buffered saline the cells were stained by 3,3'diaminobenzidine tetrahydrochloride, and the foci were counted. In each case, $\mathrm{N}$ tests were done using 50 to 100 focus (plaque)-forming units/test of each virus in Vero cells which were cultured in MEM with $5 \% \mathrm{FBS}$, and endpoints of $50 \%$ focus (plaque) reduction were recorded. Culture fluid from the virus-infected $\mathrm{C} 6 / 36$ cells was used as the stock virus solution.

\section{RESULTS}

Characterization of anti-JE virus $M A b s$

Seventeen MAbs directed against the E glycoprotein of JE virus were characterized as shown in Table 2. The antibodies showed eight reactivity patterns in the HI test, N test, ELISA and CBA as described later, and were divided into eight MAb groups. The specificity of MAbs for E protein was determined by Western blotting assay for IgG1 class or RIP for IgG2a and IgG2b. The envelope glycoprotein $\mathrm{E}$ of JE virus was precipitated as a $53000 \mathrm{~mol}$. wt. protein band with MAb N.05 in Western blotting assay, and with the other 16 MAbs in RIP assay.

\section{Reactivities of MAbs against JE virus}

Tables 3, 4, 5 and Fig. 1 show the results obtained from ELISA, $\mathrm{N}$ test, HI test and CBA, respectively. These data show eight reactivity patterns, and the 17 antibodies were divided into eight MAb groups. This suggests the existence of at least eight epitopes or antigenic sites on the $E$ protein of $\mathrm{JE}$ virus, some of which are adjacent to or overlapping each other, and some of which are distinctly separate. The epitopes on the E protein are summarized in Table 6, which shows biological functions ( $\mathrm{HI}$ and $\mathrm{N}$ ) for JE virus only and cross-reactivities (ELISA) for other flaviviruses. MAb groups 1, 2, 3, 4 and 5 have been described in detail previously (KimuraKuroda \& Yasui, 1983). Other antibodies (MAb groups 6, 7 and 8) were characterized by HI test, $\mathrm{N}$ test, ELISA and CBA. MAb group 6 (201) showed neither HI nor N activity. In contrast, antibodies N.04, N.09 and 402 (MAb group 7) showed both $\mathrm{HI}$ and $\mathrm{N}$ activity. MAb group 8 (503) showed the highest $\mathrm{N}$ activity among all the antibodies tested, but no HI activity. Using purified IgG fractions, $\mathrm{N}$ activity/protein of antibody 503 was the highest (approx. $\log _{10} 5.0 \mathrm{~N}$ titres/ $1 \mathrm{mg}$ protein).

The results of CBA (Fig. 1) suggest the topography of epitopes recognized by these MAb groups. The antigenic site of MAb group 1 seems to be distinctly separate from the other sites. The reciprocal pairs of MAb groups 2 and 3 and MAb groups 3 and 8 showed strong competition, indicating that their sites may be adjacent to each other or overlapping on the $\mathrm{E}$ protein. Since MAb group 7 incompletely inhibited the binding of MAb groups 2, 3,6 and 8, the recognition site of MAb group 7 seems to be related to the sites of the other four. None of the group 4 or 5 MAbs showed any significant competition with the the other MAb groups. On the basis of these results of CBA, it is reasonable to arrange the order of the eight MAb groups as in Tables 3, 4, 5 and 6. Even when Nak strain virus was used as the antigen, the CBA results were not affected, except for antibody 401, a JaG-specific MAb (data not shown). 
Table 2. Characterization of anti-JE virus MAbs

\begin{tabular}{|c|c|c|c|c|}
\hline $\begin{array}{c}\text { Virus for } \\
\text { immunization }\end{array}$ & $\begin{array}{l}\mathrm{MAb} \\
\text { group* }\end{array}$ & Clone & IgG subclass & $\begin{array}{l}\text { Polypeptide } \\
\text { specificity }\end{array}$ \\
\hline $\begin{array}{c}\text { JaGAr-01 } \\
(\mathrm{JaG})\end{array}$ & $\begin{array}{l}1 \\
2 \\
3 \\
4\end{array}$ & $\begin{array}{r}23 \\
111 \\
301 \\
109 \\
112 \\
401 \\
203 \\
302 \\
303 \\
204 \\
201 \\
402 \\
503\end{array}$ & $\begin{array}{l}\text { IgG2a } \\
\text { IgG2a } \\
\text { IgG2a } \\
\text { IgG2a } \\
\text { IgG2a } \\
\text { IgG2a } \\
\text { IgG2a } \\
\text { IgG2b } \\
\text { IgG2a } \\
\text { IgG2a } \\
\text { IgG2a } \\
\text { IgG2b } \\
\text { IgG2a }\end{array}$ & $\begin{array}{l}E \\
E \\
E \\
E \\
E \\
E \\
E \\
E \\
E \\
E \\
E \\
E \\
E\end{array}$ \\
\hline $\begin{array}{l}\text { Nakayama-Yoken } \\
\text { (Nak) }\end{array}$ & $\begin{array}{l}2 \\
4 \\
7\end{array}$ & $\begin{array}{l}\text { N.05 } \\
\text { N.11 } \\
\text { N.04 } \\
\text { N.09 }\end{array}$ & $\begin{array}{l}\text { IgG1 } \\
\text { IgG2b } \\
\text { IgG2b } \\
\text { IgG2b }\end{array}$ & $\begin{array}{l}E \\
E \\
E \\
E\end{array}$ \\
\hline
\end{tabular}

* The antibodies were divided into eight MAb groups based on reactivity patterns in HI test, $\mathrm{N}$ test, ELISA and CBA.

Table 3. Reactivity of MAbs in ELISA

\begin{tabular}{|c|c|c|c|c|c|c|c|c|c|c|}
\hline \multirow[b]{3}{*}{$\mathrm{MAb}$ group } & \multirow[b]{3}{*}{ MAb } & \multicolumn{9}{|c|}{$\log _{10}$ ELISA titre* } \\
\hline & & \multicolumn{3}{|c|}{ JE } & \multirow[b]{2}{*}{ MVE } & \multirow[b]{2}{*}{ WN } & \multirow[b]{2}{*}{ SLE } & \multirow[b]{2}{*}{ DEN-1 } & \multirow[b]{2}{*}{ DEN-2 } & \multirow[b]{2}{*}{ SIN } \\
\hline & & $\mathrm{JaG}$ & Mie & Nak & & & & & & \\
\hline 1 & $\begin{array}{r}23 \\
111 \\
301\end{array}$ & $\begin{array}{l}5.0 \\
5.0 \\
5.0\end{array}$ & $\begin{array}{l}5 \cdot 0 \\
5.4 \\
5.1\end{array}$ & $\begin{array}{l}5.0 \\
5.1 \\
5.0\end{array}$ & $\begin{array}{l}5 \cdot 1 \\
5 \cdot 0 \\
5 \cdot 0\end{array}$ & $\begin{array}{l}4 \cdot 6 \\
5 \cdot 0 \\
4 \cdot 6\end{array}$ & $\begin{array}{l}5 \cdot 1 \\
4.9 \\
4 \cdot 5\end{array}$ & $\begin{array}{l}4.8 \\
4.8 \\
3.8\end{array}$ & $\begin{array}{l}4.9 \\
4.8 \\
4.3\end{array}$ & $\begin{array}{l}-\dagger \\
- \\
-\end{array}$ \\
\hline 2 & $\begin{array}{r}109 \\
\text { N.05 }\end{array}$ & $\begin{array}{l}5 \cdot 0 \\
5 \cdot 0\end{array}$ & $\begin{array}{l}5 \cdot 2 \\
5 \cdot 2\end{array}$ & $\begin{array}{l}5 \cdot 2 \\
5 \cdot 3\end{array}$ & $\begin{array}{l}5 \cdot 2 \\
4 \cdot 9\end{array}$ & $\frac{4 \cdot 6}{0.9}$ & $\frac{4 \cdot 3}{1 \cdot 0}$ & - & - & $\begin{array}{l}- \\
-\end{array}$ \\
\hline 3 & $\begin{array}{l}112 \\
401\end{array}$ & $\begin{array}{l}5 \cdot 0 \\
5 \cdot 0\end{array}$ & $\begin{array}{r}4.4 \\
- \\
-\end{array}$ & 4.6 & $\begin{array}{l}1.7 \\
-\end{array}$ & $\begin{array}{c}1.5 \\
-\end{array}$ & $\begin{array}{l}- \\
-\end{array}$ & - & - & - \\
\hline 8 & 503 & $5 \cdot 0$ & $5 \cdot 0$ & 4.9 & - & - & - & - & - & - \\
\hline 7 & $\begin{array}{l}\text { N.04 } \\
\text { N.09 }\end{array}$ & $\begin{array}{l}5 \cdot 0 \\
5 \cdot 0\end{array}$ & $\begin{array}{l}5 \cdot 4 \\
5 \cdot 2\end{array}$ & $\begin{array}{l}4.9 \\
4.9\end{array}$ & $\begin{array}{l}5.0 \\
5.0\end{array}$ & $\frac{-}{3 \cdot 1}$ & $\begin{array}{c}- \\
0 \cdot 4\end{array}$ & - & $\frac{-}{2.5}$ & $\begin{array}{l}- \\
-\end{array}$ \\
\hline & 402 & $5 \cdot 0$ & 5.0 & $5 \cdot 2$ & $5 \cdot 0$ & $5 \cdot 2$ & - & - & - & - \\
\hline 6 & 201 & $5 \cdot 0$ & $5 \cdot 1$ & 4.7 & $5 \cdot 1$ & 4.6 & 0.7 & - & - & - \\
\hline 5 & 204 & $5 \cdot 0$ & $5 \cdot 2$ & $5 \cdot 1$ & $5 \cdot 0$ & $5 \cdot 0$ & - & - & - & - \\
\hline 4 & $\begin{array}{r}\text { N.11 } \\
203 \\
302 \\
303\end{array}$ & $\begin{array}{l}5 \cdot 0 \\
5 \cdot 0 \\
5 \cdot 0 \\
5 \cdot 0\end{array}$ & $\begin{array}{l}5 \cdot 0 \\
5 \cdot 0 \\
5 \cdot 0 \\
4 \cdot 6\end{array}$ & $\begin{array}{l}4.9 \\
4.7 \\
4.6 \\
4.6\end{array}$ & $\begin{array}{l}5 \cdot 1 \\
5 \cdot 0 \\
5 \cdot 1 \\
5 \cdot 0\end{array}$ & $\begin{array}{l}4 \cdot 3 \\
4 \cdot 5 \\
5 \cdot 0 \\
4.9\end{array}$ & $\begin{array}{l}1 \cdot 1 \\
3 \cdot 9 \\
4.5 \\
4 \cdot 6\end{array}$ & $\begin{array}{c}- \\
- \\
- \\
0.2\end{array}$ & $\begin{array}{l}- \\
- \\
- \\
0 \cdot 4\end{array}$ & $\begin{array}{l}- \\
- \\
-\end{array}$ \\
\hline
\end{tabular}

* Left of the bold line indicates strong reactivities ( $>\log _{10} 3 \cdot 0$ ELISA units).

$\dagger-,<0$.

In ELISA, $\mathrm{N}$ tests and $\mathrm{HI}$ assays, the MAbs showed similar reactivities against three strains of JE virus ( $\mathrm{JaG}$, Mie and Nak strains), whereas one of the group $3 \mathrm{MAbs}$, antibody 401 , reacted only with strain $\mathrm{JaG}$ (Table 3 ).

\section{Cross-reactivities of MAbs against other flaviviruses}

To analyse the cross-reactivities of 17 MAbs with five other flaviviruses, we performed ELISA, HI test and $\mathrm{N}$ tests. In Table 3, 4 and 5, left of the bold line indicates strong reactivities in ELISA, which indicates more than $\log _{10} 3 \cdot 0$ ELISA units. 


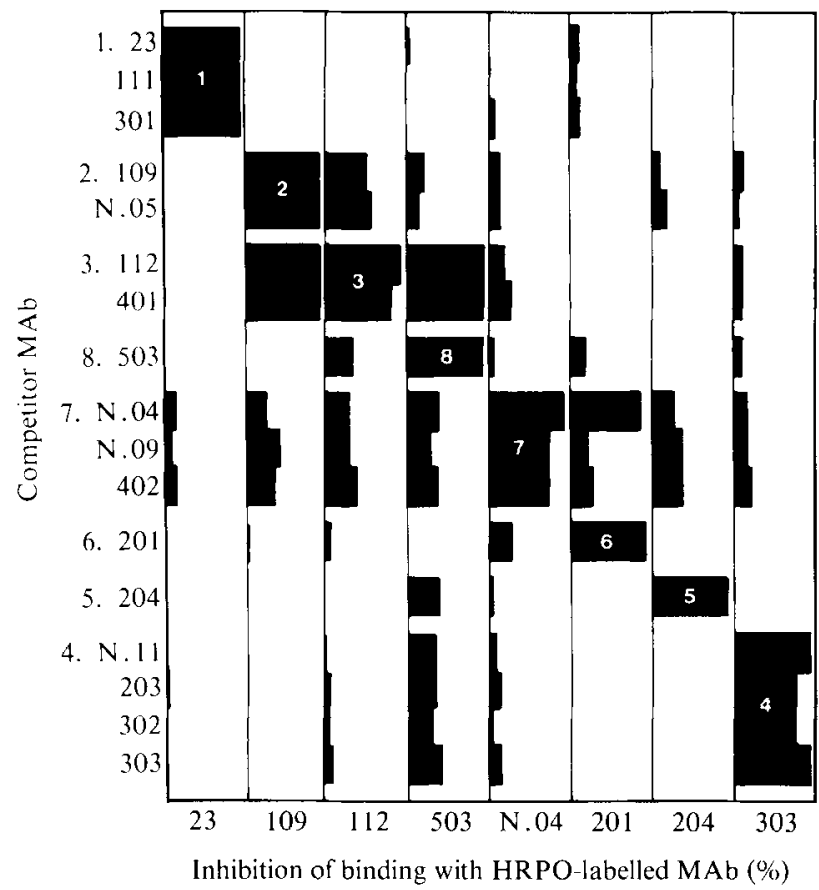

Fig. 1. Summary of CBAs. Competitors were used at the limit concentration of $\log _{10} 4.0$ ELISA units. JaG strain was used as antigen. The percentage of competition was determined by the formula $[100(\mathrm{~A}-n)] /(\mathrm{A}-\mathrm{B})$, where $\mathrm{A}$ is absorbance in the absence of competing antibody, $\mathrm{B}$ is absorbance in the presence of homologous antibody, and $n$ is absorbance in the presence of competitor.

Table 4. $N$ activities of $M A b s^{*}$ against $J E$ and other flaviviruses

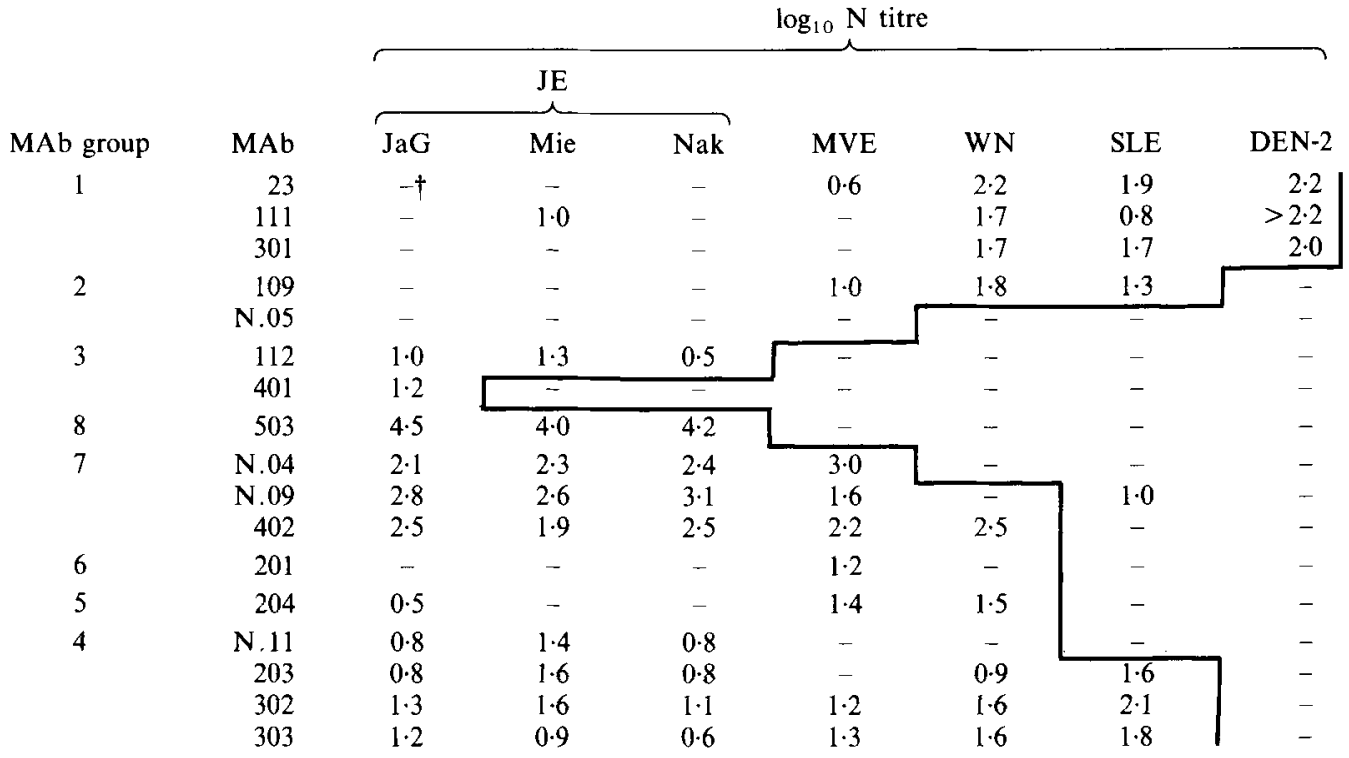

${ }^{*} \log _{10} 5 \cdot 0$ ELISA units of monoclonal antibodies (against JaG strain virus) were used. Left of the bold line indicates strong reactivities in ELISA ( $>\log _{10} 3 \cdot 0$ ELISA units).

$\dagger-,<0 \cdot 5$. 
Table 5. HI activities of $M A A^{*}$ against JE and other flaviviruses

\begin{tabular}{|c|c|c|c|c|c|c|c|c|c|}
\hline \multirow[b]{3}{*}{ MAb group } & \multirow[b]{3}{*}{$\mathrm{MAb}$} & \multicolumn{8}{|c|}{$\log _{10}$ HI titre } \\
\hline & & \multicolumn{3}{|c|}{$\mathrm{JE}$} & \multirow[b]{2}{*}{ MVE } & \multirow[b]{2}{*}{ WN } & \multirow[b]{2}{*}{ SLE } & \multirow[b]{2}{*}{ DEN-1 } & \multirow[b]{2}{*}{ DEN-2 } \\
\hline & & $\mathrm{JaG}$ & Mie & Nak & & & & & \\
\hline 1 & $\begin{array}{r}23 \\
111 \\
301\end{array}$ & $\begin{array}{l}3.8 \\
3.2 \\
3.5\end{array}$ & $\begin{array}{l}3.7 \\
3.2 \\
3.7\end{array}$ & $\begin{array}{l}3 \cdot 5 \\
2 \cdot 9 \\
3 \cdot 2\end{array}$ & $\begin{array}{l}3.7 \\
2.7 \\
3.5\end{array}$ & $\begin{array}{l}3.7 \\
2.9 \\
3.5\end{array}$ & $\begin{array}{l}3.9 \\
3 \cdot 1 \\
3 \cdot 4\end{array}$ & $\begin{array}{l}3 \cdot 5 \\
3 \cdot 1 \\
3 \cdot 2\end{array}$ & $\begin{array}{l}3 \cdot 5 \\
3 \cdot 1 \\
3 \cdot 4\end{array}$ \\
\hline 2 & $\begin{array}{r}109 \\
\text { N.05 }\end{array}$ & $\begin{array}{l}2 \cdot 3 \\
3 \cdot 1\end{array}$ & $\begin{array}{l}2 \cdot 4 \\
2 \cdot 8\end{array}$ & $\begin{array}{l}1.8 \\
2.4\end{array}$ & $\begin{array}{l}2.2 \\
1 \cdot 1\end{array}$ & $\frac{1.5}{-}$ & $\frac{1.3}{-}$ & $\begin{array}{l}- \\
-\end{array}$ & $\begin{array}{l}- \\
-\end{array}$ \\
\hline 3 & $\begin{array}{l}112 \\
401\end{array}$ & $\begin{array}{l}-\dagger \\
-\end{array}$ & $\frac{-}{-}$ & - & - & $\begin{array}{l}- \\
-\end{array}$ & - & $\begin{array}{l}- \\
-\end{array}$ & $\begin{array}{l}- \\
-\end{array}$ \\
\hline 8 & 503 & - & - & - & - & - & - & - & - \\
\hline 7 & $\begin{array}{r}\text { N.04 } \\
\text { N.09 } \\
402\end{array}$ & $\begin{array}{l}3 \cdot 2 \\
3 \cdot 8 \\
2 \cdot 5\end{array}$ & $\begin{array}{l}3 \cdot 1 \\
3.8 \\
2.5\end{array}$ & $\begin{array}{l}3 \cdot 1 \\
3 \cdot 5 \\
1 \cdot 9\end{array}$ & $\begin{array}{l}2.8 \\
1.9 \\
1.9\end{array}$ & $\frac{-}{2.5}$ & $\begin{array}{l}- \\
- \\
-\end{array}$ & $\begin{array}{l}- \\
- \\
-\end{array}$ & $\begin{array}{l}- \\
- \\
-\end{array}$ \\
\hline 6 & 201 & - & - & - & 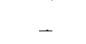 & - & - & - & - \\
\hline 5 & 204 & - & - & - & - & - & - & - & - \\
\hline 4 & $\begin{array}{r}\text { N.11 } \\
203 \\
302 \\
303\end{array}$ & $\begin{array}{l}- \\
- \\
- \\
-\end{array}$ & $\begin{array}{l}- \\
- \\
- \\
-\end{array}$ & $\begin{array}{l}- \\
- \\
- \\
-\end{array}$ & $\begin{array}{l}- \\
- \\
- \\
-\end{array}$ & $\begin{array}{l}- \\
- \\
- \\
-\end{array}$ & $\begin{array}{l}- \\
- \\
- \\
-\end{array}$ & $\begin{array}{l}- \\
- \\
-\end{array}$ & $\begin{array}{l}- \\
- \\
- \\
-\end{array}$ \\
\hline
\end{tabular}

* $\log _{10} 5 \cdot 0$ ELISA units of monoclonal antibodies (against JaG strain virus) were used. Left of the bold line indicates strong reactivities in ELISA ( $>\log _{10} 3 \cdot 0$ ELISA units).

$\dagger-,<0 \cdot 5$.

Table 6. Summary of epitopes on the E protein of JE virus

Epitopes*
recognized by
MAb group 1
$\left\{\begin{array}{l}2 \\ 3 \\ 8 \\ 7 \\ 6 \\ 5 \\ 4\end{array}\right.$

Biological functions
against JE virus

$\mathrm{HI}++\mathrm{N}-$

$\mathrm{HI}++\mathrm{N}-$

$\mathrm{HI}-\mathrm{N}+$

$\mathrm{HI}-\mathrm{N}+++$

$\mathrm{HI}++\mathrm{N}++$

$\mathrm{HI}-\mathrm{N}-$

$\mathrm{HI}-\mathrm{N}+$

$\mathrm{HI}-\mathrm{N}+$

\section{Cross-reactivity}

Flavivirus cross-reactive $\dagger$

Subgroup-reactive

JE virus-specific, strain-specific

JE virus-specific

Subgroup-reactive

Subgroup-reactive

Subgroup-reactive

Subgroup-reactive

* The epitopes of reciprocal pairs of MAb groups 2 and 3 and MAb groups 3 and 8 may be adjacent to or overlapping each other. The site of MAb group 7 seems to be related to those of MAb groups 2, 3,6 and 8 .

$\dagger$ MAb group 1 cross-reacted with DEN (types 1, 2, 3 and 4) and YF viruses.

As shown in Table 3, the results clearly indicate the following. (i) None of the antibodies reacted with Sindbis virus. (ii) All MAbs except for those in groups 3 and 8 showed strong crossreactions with MVE virus. (iii) Some MAb group 2 and 7 antibodies, 109 and 402, and all of MAb group 1, 4, 5 and 6 antibodies showed similar cross-reactivity with WN virus. (iv) Several MAb group 2 and 4 antibodies, 109, 203, 302 and 303, and all MAb group 1 antibodies crossreacted with SLE virus. (v) Only MAb group 1 showed a cross-reaction with the other subgroup DEN viruses, and also with the separate subgroup YF virus as described previously (KimuraKuroda \& Yasui, 1983). These results are summarized in the right-hand column of Table 6.

The $\mathrm{N}$ activities against other flaviviruses are presented in Table 4. Antibody 503 (MAb group 8), possessing the highest $\mathrm{N}$ activity, reacted only with $\mathrm{JE}$ virus, but not with the other flaviviruses. All antibodies of MAb group 7, which showed rather high $\mathrm{N}$ activities against JE 
Table 7. Mixing effects of MAbs on $N$ activity

\begin{tabular}{|c|c|c|c|c|c|c|}
\hline \multirow{2}{*}{\multicolumn{2}{|c|}{ Virus }} & \multicolumn{3}{|c|}{$\mathrm{N}$ titre of mixtures* } & \multirow{2}{*}{$\begin{array}{c}\text { Expected } \\
\mathrm{N} \text { titre }\end{array}$} & \multirow{2}{*}{$\begin{array}{l}\text { Increased } \\
\text { ratio }\end{array}$} \\
\hline & & 1 & 2 & 3 & & \\
\hline $\mathrm{JE}$ & $\mathrm{JaG}$ & 2220 & - & - & 510 & 4.4 \\
\hline & Mie & 970 & - & - & 89 & 10.9 \\
\hline & Nak & 422 & - & - & 122 & 3.5 \\
\hline M & & 5120 & - & - & 647 & 7.9 \\
\hline Wl & & $-\dagger$ & 4457 & - & 836 & $5 \cdot 3$ \\
\hline SL & & - & - & 2229 & 280 & 8.0 \\
\hline
\end{tabular}

\footnotetext{
* Mixture 1: MAb group 1, 2, 3, 4, 5, 7 (301, 109, 112, 303, 204, N.04). Mixture 2: MAb group 1, 2, 3, 4, 5, 6, 7 $(301,109,112,302,204,201,402)$. Mixture 3: MAb group 1, 2, 4 (301, 109, 302).

$\dagger-$, Not done.
}

virus, also neutralized MVE virus, and only one of them, antibody 402, neutralized WN virus. On the other hand, some cross-reactive MAbs in ELISA neutralized the other flaviviruses despite having no $\mathrm{N}$ activity against the JE virus. MAb group 1 neutralized WN, SLE and DEN-2 viruses, although it did not show any $N$ activities against JE and MVE viruses. Antibody 109 of MAb group 2 showed low N activity against MVE, WN and SLE viruses, but not against $\mathrm{JE}$ virus.

As shown in Table $5(\mathrm{HI})$, the MAbs cross-reactive in ELISA (left of the bold line in Table 5) showed a similar pattern in HI activity against JE and other flaviviruses, except that antibody N.09 showed no HI activity against WN virus.

\section{Synergistic neutralization by MAb mixtures against other flaviviruses}

Since synergistic $\mathrm{N}$ of JE virus was caused by mixtures of several MAb groups which showed different reactivity patterns as previously described (Kimura-Kuroda \& Yasui, 1983), we performed $\mathrm{N}$ tests with the other flaviviruses of the $\mathrm{WN}$ subgroup using such mixtures (Table 7). When several antibodies from different MAb groups cross-reacting with each virus were mixed, the $\mathrm{N}$ activities of the mixtures were approximately 3.5 to 10.9 times higher than that expected by simple dilution of the activity of the $\mathrm{N}$ antibody. Similar results were obtained using other mixtures of different cross-reactive MAbs. On the other hand, mixtures including MAb group 8 (503) and the other antibodies did not show any synergistic effect on neutralization (N) of JE virus (data not shown).

\section{DISCUSSION}

Cross-reactivities in ELISA (Table 3) demonstrate that JE virus is antigenically close to the WN subgroup viruses tested, while being distant from the other subgroup DEN viruses. In particular, 14 out of 17 MAbs cross-reacted with MVE virus, indicating that the E protein of JE virus might be antigenically closest to that of MVE virus among the WN subgroup viruses tested. Our findings were supported by evidence that polyclonal hyperimmune serum against JE or MVE viruses showed strong cross-reactions with each other in comparison with other viruses in the WN subgroup (Pond et al., 1955). However, Chamberlain (1980) reported that the epidemiology of JE and MVE viruses did not show any overlapping areas; JE virus occurs in eastern Asia from Japan and southeastern U.S.S.R. to Indonesia and India, whereas MVE virus occurs in Australia and New Guinea. It is interesting that there is a great resemblance in the antigenic structure of the $\mathrm{E}$ protein of JE and MVE viruses, although they are geographically separated. WN virus appears to be relatively close to JE virus, while SLE virus is the least close of the three. WN virus has been reported from much of Africa, the Near East, the U.S.S.R., parts of Europe, India and Indonesia, whereas SLE virus occurs in North, Central and South America. It is unclear whether or not the antigenic relationships among WN subgroup viruses reflect their geographical distribution.

The results of $\mathrm{N}$ tests indicate that one of the critical $\mathrm{N}$ sites is composed of the site $\mathrm{MAb}$ group 8 (503), and that it is JE virus-specific. Antibody 503 showed the highest $\mathrm{N}$ activity among 
N MAbs, and neutralized only JE virus but not the other flaviviruses. All MAb group 7 antibodies showed rather high $\mathrm{N}$ activity against JE and MVE viruses, and one of them (antibody 402) cross-neutralized WN virus. The recognized site of MAb group 3 which is closely related to the $\mathrm{N}$ site of MAb group 8 showed JE virus specificity or JaG strain specificity. Recently, we observed that a Nak strain-specific MAb was also closely related to the MAb group 8 site in CBA (unpublished data). These facts suggest that there is a variable region (MAb groups 3, 7 and 8 ) in the E protein gene, which must be important for infection of the JE virus. This was supported by the fact that at least one of the critical $\mathrm{N}$ sites has been determined to be virus-specific in other flaviviruses, namely SLE (Roehrig et al., 1983) and TBE (Heinz et al., 1983) viruses.

On the other hand, at least one site recognized by $\mathrm{HI}$ antibodies is conserved, because MAb group 1 cross-reacted with other subgroup DEN viruses (Table 5) and separate subgroup YF virus (Kimura-Kuroda \& Yasui, 1983). These facts are consistent with the evidence that antiflavivirus serum shows high cross-reactivity in HI but low cross-reactivity in N test (Porterfield, 1980). Interestingly, all MAb group 1 antibodies showed low but significant $\mathrm{N}$ activities against WN, SLE and DEN-2 viruses, although they hardly neutralized JE and MVE viruses. A similar observation was also made in the case of antibody 109 (MAb group 2). These facts suggest that the conformational structure and/or biological function of the antigenic sites on the $E$ protein of WN, SLE and DEN-2 viruses recognized by MAb group 1 or 2 may be different from those of JE and MVE viruses, which show an almost similar pattern in $\mathrm{HI}$ and $\mathrm{N}$ tests. Similar observations have been reported in the case of Venezuelan equine encephalomyelitis virus (Roehrig \& Mathews, 1985). The sites of MAb groups 1 and 2 may be important for infection of DEN-2, WN and SLE viruses.

Our observations suggest that the main antigenic structure of the three strains of JE virus ( $\mathrm{JaG}$, Mie and Nak) is homologous, because there is no significant difference of pattern in ELISA, HI and N tests by anti-JE MAbs, except for JaG-specific antibody 401 (MAb group 3). Many strains of JE virus isolated from patients or mosquitoes have been divided into three types ( $\mathrm{JaG}, \mathrm{Nak}$ and other) by serological $\mathrm{HI}$ and $\mathrm{N}$ tests (Oya et al., 1960). This typing was confirmed by Kobayashi et al. (1984) using anti-JE HI MAbs. Antigenicity of purified E (V3) protein of two JE virus strains was compared previously (Takegami et al., 1982b). It is important to determine whether or not the antigenic sites, possessing strain specificity, are necessary for virus infection, because it is not always certain that vaccination with the vaccine strains will be effective in protection from infection by all strains of JE virus. The site of MAb group 8, which may be important for $\mathrm{JE}$ virus infection, seems to be conserved among $\mathrm{JE}$ virus strains, and, interestingly, the sites of strain-specific antibodies are closely related to this site in our data.

Previously, we reported that mixtures of MAbs synergistically increased the $\mathrm{N}$ activity against JE virus (Kimura-Kuroda \& Yasui, 1983). In three viruses of the WN subgroup, this synergism was also observed using mixtures of anti-JE MAbs from different MAb groups. Some investigators have reported that the binding of antibodies to certain epitopes on virus protein induces conformational changes in distant parts of the molecule and results in the increased avidity of other antibodies (Clegg et al, 1983; Heinz et al., 1984a; Lubeck \& Gerhard, 1982). Such conformational changes or steric hindrance of important $\mathrm{N}$ sites for virus infection may cause the synergistic $\mathrm{N}$ of other flaviviruses. Antibody 503 (MAb group 8), possessing the highest $\mathrm{N}$ activity, did not show any synergistic $\mathrm{N}$ activity against $\mathrm{JE}$ virus with the other MAbs, but the other antibodies reacting with each virus increased $\mathrm{N}$ activities against $\mathrm{JE}$, MVE, WN and SLE viruses. This suggests that the critical N sites of three WN subgroup viruses, MVE, WN and SLE, may not be detected by these 17 MAbs. Although critical N sites seem to exist on the viral protein of several flaviviruses (TBE, SLE and JE viruses) (Heinz et al., 1983; Roehrig et al., 1983), synergistic $\mathrm{N}$ may play an important role in in vivo protection from virus infection and cause cross- $\mathrm{N}$ of the other subgroup flaviviruses.

It is important that cross-reactive antibodies can enhance the replication of certain flaviviruses (Gollins \& Porterfield, 1984; Peiris et al., 1982; Schlesinger \& Brandriss, 1983; Ueba, 1982), especially DEN viruses (Halstead et al., 1984). In fact, epidemics of both JE and DEN virus diseases have been serious in Southeast Asia and it is not yet known whether this 
enhancing antibody causes severe diseases or not. Enhancement of JE or DEN virus infectivity by anti-JE MAbs was confirmed by observation in a mouse macrophage cell line, P388D1 (unpublished data). To establish more effective and secure vaccines, further investigations are needed to determine which antigenic determinants on virus protein cause the enhancement of virus replication by the binding of antibody.

We are indebted to Dr Tsutomu Takegami for advice concerning RIP and Western blotting. We also thank Ms Mami Washizu for obtaining hybridoma clones. This investigation was supported in part by grants 58570217 , 58770362, 59570205 and 59771734 from the Ministry of Education, Science and Culture of Japan.

\section{REFERENCES}

Bell, J. R., KinNey, R. M., TRent, D. W., Lenches, E. M., Dalgarno, L. \& STrauss, J. H. (1985). Amino-terminal amino acid sequences of structural proteins of three flaviviruses. Virology 143, 224-229.

BUCKLEY, A. \& GOULD, E. A. (1985). Neutralization of yellow fever virus studied using monoclonal antibodies. Journal of General Virology 66, 2523-2531

Chamberlain, R. W. (1980). Epidemiology of arthropod-borne toga-viruses: the role of arthropods as hosts and vectors and of vertebrate hosts in natural transmission cycles. In The Togaviruses, pp. 175-227. Edited by R. W. Schlesinger. New York: Academic Press.

ClARKE, D. H. \& CASALS, J. (1958). Techniques for hemagglutination and hemagglutination inhibition with arthropod-borne viruses. American Journal of Tropical Medicine and Hygiene 7, 561-573.

CleGG, J. C. S., CHANaS, A. C. \& Gould, E. A. (1983). Conformational changes in Sindbis virus El glycoprotein induced by monoclonal antibody binding. Journal of General Virology 64, 1121-1126.

GENTRY, M. K., HENCHAL, E. A., MCCOWN, J. M., BRANDT, W. E. \& DALRYMPLE, J. M. (1982). Identification of distinct antigenic determinants on dengue-2 virus using monoclonal antibodies. American Journal of Tropical Medicine and Hygiene 31, 548-555.

GOLLINS, S. W. \& PORTERFIELD, J. S. (1984). Flavivirus infection enhancement in macrophages: radioactive and biological studies on the effect of antibody on viral fate. Journal of General Virology 65, 1261-1272.

GOULD, E. A., BUCKLEY, A., CAMMACK, N., BARRETT, A. D. T., CLEGG, J. C. S., ISHAK, R. \& VARMA, M. G. R. (1985). Examination of the immunological relationships between flaviviruses using yellow fever virus monoclonal antibodies. Journal of General Virology 66, 1369-1382.

HALSTEAD, S. B., VENKATESHAN, C. N., GENTRY, M. K. \& LARSEN, L. K. (1984). Heterogeneity of infection enhancement of dengue 2 strains by monoclonal antibodies. Journal of Immunology 132, 1529-1532.

HEINZ, F. X., BERGER, R., TUMA, W. \& KUNZ, C. (1983). A topological and functional model of epitopes on the structural glycoprotein of tick-borne encephalitis virus defined by monoclonal antibodies. Virology 126, 525-537.

HEINZ, F. X., MANDL, C., BERGER, R., TUMA, W. \& KUNZ, C. (1984a). Antibody-induced conformational changes result in enhanced avidity of antibodies to different antigenic sites on the tick-borne encephalitis virus glycoprotein. Virology 133, 25-34.

HEINZ, F. X., TUMA, W., GUIRAKHOO, F., BERGER, R. \& KUNZ, C. (1984b). Immunogenicity of tick-borne encephalitis virus glycoprotein fragments : epitope-specific analysis of the antibody response. Journal of General Virology 65, 1921-1929.

KIMURA-KURODA, J. \& YASUI, K. (1983). Topographical analysis of antigenic determinants on envelope glycoprotein V3 (E) of Japanese encephalitis virus, using monoclonal antibodies. Journal of Virology 45, $124-132$.

KIMURA-KURODA, J. \& YASUI, K. (1985). A focus assay method for Japanese encephalitis virus using complement and anti-virus serum. Microbiology and Immunology 29, 55-63.

KOBAYASHI, Y., HASEGAWA, H., OYAMA, T., TAMAI, T. \& KUSABA, T. (1984). Antigenic analysis of Japanese encephalitis virus by using monoclonal antibodies. Infection and Immunity 44, 117-123.

LAEMMLI, U. K. (1970). Cleavage of structural proteins during the assembly of the head of bacteriophage T4. Nature, London 227, 680-685.

LUBECK, M. D. \& GERHARD, W. (1982). Conformational changes at topologically distinct antigenic sites on the influenza $\mathrm{A} / \mathrm{PR} / 8 / 34$ virus HA molecule are induced by the binding of monoclonal antibodies. Virology 118, $1-7$.

MADRID, A. T. DE \& PORTERFIELD, J. S. (1974). The flaviviruses (group B arboviruses): a cross-neutralization study. Journal of General Virology 23, 91-96.

MATHEWS, J. H. \& ROEHRIG, J. T. (1984). Elucidation of the topography and determination of the protective epitopes on the E glycoprotein of Saint Louis encephalitis virus by passive transfer with monoclonal antibodies. Journal of Immunology 132, 1533-1537.

MORI, H., NAKAI, H. \& NOJIMA, T. (1965). The interaction of Japanese encephalitis virus with its receptor prepared from pigeon red blood cells and susceptible cells. Acta virologica 9, 97-108.

NAKANE, P. K. \& KAWAOI, A. (1974). Peroxidase-labelled antibody: a new method of conjugation. Journal of Histochemistry and Cytochemistry 22, 1084-1091.

OKUNO, Y., SASAO, F., FUKUNAGA, T. \& FUKAI, K. (1977). An application of PAP (peroxidase-anti-peroxidase) staining technique for the rapid titration of dengue virus type 4 infectivity. Biken Journal $20,29-33$.

OYA, A., OKUNO, T., OGATA, T., TAKAHASHI, M. \& KOBAYASHI, I. (1960). Annual report of the arbovirus study group of the NIH of Japan in the year 1960, pp. 25-34. 
PEIRIS, J. S. M., PORTER FIELD, J. S. \& ROEHRIG, J. T. (1982). Monoclonal antibodies against the flavivirus West Nile. Journal of General Virology 58, 283-289.

POND, W. L., RUSS, S. B., ROGERS, N. G. \& SMADEL, J. E. (1955). Murray Valley encephalitis virus: its serological relationship to the Japanese-West Nile-St. Louis encephalitis group of viruses. Journal of Immunology 75, 7884.

PORTERFIELD, J. S. (1980) Antigenic characteristics and classification of Togaviridae. In The Togaviruses, pp. 1346. Edited by R. W. Schlesinger. New York: Academic Press.

ROEHRIG, J. T. \& MATHEWS, J. H. (1985). The neutralization site on the E2 glycoprotein of Venezuelan equine encephalomyelitis (TC-83) virus is composed of multiple conformationally stable epitopes. Virology 142, 347356.

ROEHRIG, J. T., MATHEWS, J. H. \& TRENT, D. W. (1983). Identification of epitopes on the E glycoprotein of Saint Louis encephalitis virus using monoclonal antibodies. Virology 128, 118-126.

SCHLESINGER, J. J. \& BRANDRISS, M. W. (1983). 17D yellow fever virus infection of P388D, cells mediated by monoclonal antibodies: properties of the macrophage Fc receptor. Journal of General Virology 64, 1255-1262.

TAKEGAMI, T., MIYAMOTO, H., NAKAMURA, H. \& YASUI, K. (1982a). Biological activities of the structural proteins of Japanese encephalitis virus. Acta virologica 26, 312-320.

TAKEGAMI, T., MIYAMOTO, H., NAKAMURA, H. \& YASUI, K. (1982b). Differences in biological activity of the V3 envelope protein of two Japanese encephalitis virus strains. Acta virologica 26, 321-327.

TAKEGAMI, T., SEMLER, B. L., ANDERSON, C. W. \& WIMMER, E. (1983). Membrane fractions active in poliovirus RNA replication contain VPg precursor polypeptides. Virology 128, 33-47.

TOWBIN, H., STAEHELIN, T. \& GORDON, J. (1979). Electrophoretic transfer of proteins from polyacrylamide gels to nitrocellulose sheets: procedure and some applications. Proceedings of the National Academy of Sciences, U.S.A. 76, 4350-4354.

UEBA, N. (1982). Infectivity enhancement of Japanese encephalitis virus on BHK-21 cell cultures by anti-JEV mouse sera. Journal of the Yonago Medical Association 33, 405-429.

WESTAWAY, E. G., BRINTON, M. A., GAIDAMOVICH, S. YA., HORZINEK, M. C., IGARASHI, A., KÄÄRIÄINEN, L., LVOV, D. K., PORTERFIELD, J. S., RUSSEL, P. K. \& TRENT, D. W. (1985). Flaviviridae. Report of the Togaviridae Study Group, Vertebrate Virus Subcommittee, International Committee on Taxonomy of Viruses. Intervirology 24, 183192.

(Received 20 May 1986) 